\title{
Hemodynamic Effects of Isoproterenol in Canine Endotoxin Shock
}

\author{
Boleslaw Starzecki and Wesley W. Spink \\ From the Department of Medicine, University of Minnesota Medical School, \\ Minneapolis, Minnesota 55455
}

A в S T R A C T Myocardial function and peripheral hemodynamic alterations were measured through the late stages of canine endotoxin shock. $60 \mathrm{~min}$ postendotoxin paired animals were given infusions of either $5 \mathrm{ml} / \mathrm{kg}$ per hr of $5 \%$ dextrose or dextrose plus isoproterenol $(0.25 \mu \mathrm{g} / \mathrm{kg}$ per $\mathrm{min})$. Comparable blood lactic and pyruvic acid levels were determined, the excess lactic acid calculated, and $\mathrm{pH}$ values were obtained. During the initial stages the classic pattern of hemodynamic alterations was observed; an excess of lactic acid appeared and the $\mathrm{pH}$ decreased. Outstanding was evidence of markedly reduced myocardial function in the late stages of shock with progressive rise in left ventricular end diastolic pressure (LVEDP), low cardiac index, rise of central venous pressure, increased central blood volume, tachycardia, and declining arterial pressure. Analyses of left ventricular function curves also indicated myocardial failure.

Infusion of dextrose alone failed to decrease mortality rate (10 of 18 dying), whereas the rate was significantly decreased with isoproterenol (2 of 18). Dextrose infusion did not benefit myocardial function. Isoproterenol resulted in a marked improvement in myocardial action with a significant increase in heart work associated with, yet very minor, increments of LVEDP. In addition, tachycardia subsided, peripheral resistance decreased, and the blood pressure stabilized. The

Address requests for reprints to Dr. Wesley W. Spink, University of Minnesota Hospitals, Minneapolis, Minn. 55455.

Received for publication 14 September 1967 and in revised form 21 June 1968. prognostic value of excess lactic acid was doubtful but a progressive fall in later stages was associated with survival.

\section{INTRODUCTION}

The pattern of hemodynamic changes in experimental endotoxin shock has been well documented (1-3). Reversal of these changes has been attempted with a variety of agents, including isoproterenol, a potent beta adrenergic stimulant. This drug has reversed the severe hemodynamic and pulmonary alterations in sheep (4) and has been confirmed in dogs $(5,6)$. Isoproterenol has significantly reduced the mortality in canine endotoxin shock (7). Various studies have shown that it increases cardiac output (8), dilates lower respiratory airways, relaxes arterioles, constricts veins, increases ventilation (9) and improves function of the failing heart $(10,11)$.

Endotoxin does not have any primary action on the myocardium during the initial stages of experimental shock. The early fall in cardiac output is prevented by maintaining an adequate venous return (12), or by decreasing splanchnic pooling (13). Transient myocardial weakness has been related to reduced coronary flow induced by hypotension (14), whereas others (15) have suggested a depressant effect of endotoxin on myocardial contractility.

The present experiments were designed to examine the effect of endotoxin on myocardial function and to evaluate the effects of isoproterenol on cardiac function and other hemodynamic alterations. In an assessment of tissue oxygenation, 
metabolic studies included determinations of blood lactate, pyruvate, and $\mathrm{pH}$.

\section{METHODS}

Endotoxin. A single lot of Escherichia coli endotoxin of the Boivin type prepared in our laboratory was used (16).

Animals and experimental design. Experiments were performed on 46 adult mongrel dogs that included both sexes. They were anesthetized with pentobarbital (30 $\mathrm{mg} / \mathrm{kg}$ ) and maintained under light anesthesia. Polyethylene catheters were introduced through a femoral artery into the lower abdominal aorta and either into the left ventricle or to the root of the aorta. Catheters were also passed through a femoral vein into the right atrium and inferior vena cava. The latter was used for injections. Aortic blood pressure was continuously recorded in all the dogs. In 24 dogs right auricular pressure (central venous pressure, CVP) and in 19 dogs the left ventricular end diastolic pressure (LVEDP) were monitored. All pressure recordings were made with pressure transducers (Statham P23AA, Sanborn 267A, and Sanborn 268A) connected to a direct writing recording system. ${ }^{1}$ The zero pressure level of each animal was ascertained by selecting a point on the anterior chest wall two-thirds of the distance from the sternal notch to the xyphoid process, and then perpendicular to this point the level was arrived at two-thirds of the distance of the anterior-posterior thoracic diameter (17).

Cardiac outputs were determined by injecting indocyanine green (Cardio-Green) ${ }^{2}$ into the right atrium and continually sampling blood at the root of the aorta with the aid of a withdrawal pump (18). The dye concentrations were measured with a Waters' cuvette and PD-densitometer and recorder. ${ }^{3}$ Blood was returned to the animal after measurement. The recorded curves were analyzed and the mean circulation times (MCT) were calculated (19). MCT was corrected for cathetercuvette volume and expressed in seconds. Cardiac outputs were calculated in liters $/ \mathrm{min}$, and then related to 1 meter $^{2}$ of body surface area and subsequently referred to as cardiac index. A standard formula, utilizing animal body weight, was used to calculate surface area (20). Basic formulas for derived physiological parameters ${ }^{4}$ were (a) Total peripheral resistance (TPR) (dynes-sec$\left.\mathrm{cm}^{-5}\right)=$ [arterial pressure $(\mathrm{mm} \mathrm{Hg})-C V P(\mathrm{~mm} \mathrm{Hg})$ ] $\times 1332 \times 60 /$ cardiac output $(\mathrm{ml} / \mathrm{min}) ;(b)$ Heart work/ stroke per $\mathrm{m}^{2}\left(\mathrm{gm}-\mathrm{m} / \mathrm{m}^{-2}\right)=$ cardiac output $(\mathrm{ml} / \mathrm{min}) \times$ (arterial pressure-CVP) $\times 13.6 / 1000 \times$ body surface area

\footnotetext{
${ }^{1}$ Model 7714 and Twin-Viso, Sanborn Co., Waltham, Mass.

${ }^{2}$ Supplied by Hynson, Westcott and Dunning, Inc., Baltimore, Md.

3 Waters Corp., Rochester, Minn.

4 The formula for heart work disregards kinetic energy and concerns left ventricle performance. Central blood volume $(\mathrm{CBV})$ represents blood volume between the point of injection in the right atrium and the sampling site in the root of the aorta. CBV was expressed as $\mathrm{ml} / \mathrm{kg}$.
}

$\left(\mathrm{m}^{2}\right) \times$ heart rate; $(c)$ Heart work/min per $\mathrm{m}^{2}$ (gm-m/ $\left.\mathrm{m}^{-2}\right)=$ cardiac output $(\mathrm{ml} / \mathrm{min}) \times($ arterial pressureCVP) $\times 13.6 / 1000 \times$ body surface area $\left(\mathrm{m}^{2}\right) ;(d)$ Central blood volume (CBV) $\mathrm{ml} / \mathrm{kg}$ of body wt $=$ cardiac output $(\mathrm{ml} / \mathrm{sec}) \times \mathrm{MCT}(\mathrm{sec}) /$ body wt $(\mathrm{kg})$; and $(e)$ Stroke index $\left(\mathrm{ml} / \mathrm{m}^{2}\right)=$ cardiac output $(\mathrm{ml} / \mathrm{min}) /$ body surface area $\left(\mathrm{m}^{2}\right) \times$ heart rate.

Blood lactic acid determinations on whole arterial blood in $10 \mathrm{dogs}$ were done by the method of Barker and Summerson (21), and in 26 dogs by an enzymatic spectrophotometric method. ${ }^{5}$ In the first 10 dogs the procedure of Goldberg, Nitowsky, and Colowick was employed for pyruvic acid estimation (22). ${ }^{6}$ In the remaining 26 dogs the enzymatic spectrophotometric method was used. ${ }^{5}$ Excess lactic acid was calculated according to Huckabee's formula (23). The data were subjected to statistical analysis using standard methods $(24,25)$.

A single intravenous dose of $0.75 \mathrm{mg} / \mathrm{kg}$ of body weight of endotoxin was given rapidly. Pressure measurements, heart and respiratory rates, and cardiac output were recorded before injection and at postendotoxin intervals of $5,15,30$, and $60 \mathrm{~min}$, and at $2,4,7,10$, and $13 \mathrm{hr}$. Cardiac outputs and collections of arterial blood samples of $3 \mathrm{ml}$ after control measurements were commenced at $15 \mathrm{~min}$ postendotoxin. Measurements on blood included: lactate, pyruvate, and $\mathrm{pH}$. The following were determined at the same time: total peripheral resistance (TPR), stroke index, heart work/min, heart work/ stroke index, mean circulation time (MCT), and central blood volume ( $\mathrm{CBV})$.

Groups of animals. Experiments were conducted on a pair of dogs simultaneously. At $60 \mathrm{~min}$ after endotoxin, infusions of $5 \mathrm{ml} / \mathrm{kg}$ per hr with constant infusion pumps were started; one dog (group I) receiving $5 \%$ dextrose and another (group II), dextrose and isoproterenol 7 $(0.25 \mu \mathrm{g} / \mathrm{kg}$ per $\mathrm{min})$. In the first five pairs, infusion was given for $4 \mathrm{hr}$ and in the remaining 13 pairs, for $12 \mathrm{hr}$. At the completion of the infusion living dogs were returned to their cages and were observed up to $72 \mathrm{hr}$. Animals alive at $72 \mathrm{hr}$ postendotoxin were considered survivors.

Five control dogs receiving no endotoxin were employed to measure arterial blood pressure and LVEDP. $1 \mathrm{hr}$ after control measurements an infusion of $5 \%$ dextrose was started and administered in the same dose as in the foregoing animals for $10 \mathrm{hr}$ in order to determine the infusion effect on LVEDP.

In constructing a normal curve for left ventricular function, data were obtained in another group of five dogs given dextrose infusion, but no endotoxin, and cardiac outputs and LVEDP were measured.

5 Biochemica test combinations for lactic acid and pyruvic acid, Boehringer Mannheim Corporation, New York.

${ }^{6} \mathrm{We}$ are indebted to Dr. Paul Strandjord of the Chemistry Laboratories, University Hospitals, Minneapolis, Minn., for assistance in the determinations.

${ }^{7}$ Supplied as Isuprel by Winthrop Laboratories, New York. 


\section{RESULTS}

\section{Hemodynamic alterations after endotoxin}

In group I dogs receiving $5 \%$ dextrose and those in group II receiving isoproterenol and dextrose, the preendotoxin hemodynamic measurements and the 5-15 min postendotoxin alterations were comparable. Table I shows changes in both groups relative to arterial blood pressure, CVP, LVEDP, heart and respiratory rates.

Arterial pressure fell sharply following endotoxin, $41 \%$ of the base line value being recorded within $5 \mathrm{~min}$ in both groups. At $60 \mathrm{~min} 55 \%$ of the baseline in group I and $57 \%$ in group II were observed. These differences before and $60 \mathrm{~min}$ postendotoxin were significant in both groups $(P<0.001)$. The mean pressure in group I gradually increased, but reached a maximum of only $76 \%$ at $4 \mathrm{hr}$. Beginning $10 \mathrm{hr}$ postendotoxin pressure declined gradually to $53 \%$ at $13 \mathrm{hr}$, which was significantly lower than the base line $(P<$ $0.05)$. In group II the pressure rose, reaching a maximum of $87 \%$ of the base line at $7 \mathrm{hr}$ and then remained essentially unchanged through $13 \mathrm{hr}$.

Central venous pressure decreased in both groups after endotoxin but returned to the range of control values at $60 \mathrm{~min}$. In group I, CBP rose progressively and at $13 \mathrm{hr}$ it was twice the preendotoxin value. The difference was highly significant $(P<0.001)$. In contrast, no rise was observed in group II.

Left ventricular end diastolic pressure was sharply reduced after endotoxin, but returned to slightly lower base line levels in both groups at 60 min. LVEDP rose progressively in group $I$ and at $13 \mathrm{hr}$ postendotoxin it was four times the preendotoxin value, a highly significant difference $(P<$ $0.001)$. No similar increase was observed in group II.

Heart rate fell immediately after endotoxin but returned to control levels in both groups at 60 min. There was no significant change in the rate in group I through $13 \mathrm{hr}$. In group II maximum increase in rate was observed after $2 \mathrm{hr}$, being $25 \%$ above the preendotoxin value. Although a continuous infusion of isoproterenol was carried out, the rate decreased progressively to control values at $13 \mathrm{hr}$.

Respiratory rate increased after endotoxin and at $60 \mathrm{~min}$ was $95 \%$ above the base line in group I and $87 \%$ in group II. The increase was highly significant with values of $P<0.005$ and $P<$ 0.001 , respectively. The rate remained elevated throughout in group I with a value of $70 \%$ above base line at $13 \mathrm{hr}$ postendotoxin. The increase was statistically significant $(P<0.005)$. In group II the rate increased steadily, reaching a level twice that of the control period at $13 \mathrm{hr}$. The difference was significant $(P<0.02)$.

Table II shows the effects of endotoxin on cardiac index, total peripheral resistance, mean circulation time, central blood volume, stroke index, and heart work.

Cardiac index 15 min postendotoxin declined to 48 and $43 \%$ of the base line in groups I and II, respectively, and was 65 and $67 \%$ at $60 \mathrm{~min}$. These differences between control measurements and $60 \mathrm{~min}$ were significant $(P<0.05$ in both groups). Cardiac index in group I remained below the base line through the infusion period, being only $62 \%$ at $13 \mathrm{hr}$, a significant decline from control level $(P<0.05)$. Group II showed a progressive rise in cardiac index, reaching a maximum at $7 \mathrm{hr}$, which was $42 \%$ above the base line, and at $13 \mathrm{hr}$ was $22 \%$ above the control level, an elevation which was not significant.

Stroke index followed the changes of cardiac index, decreasing at $15 \mathrm{~min}$ to 50 and $43 \%$ of the base line values in group I and II, respectively, and 66 and $61 \%$ at $60 \mathrm{~min}$. Stroke index in group I remained low throughout the infusion period with a value of $80 \%$ at $13 \mathrm{hr}$ postendotoxin, which was significantly lower than the preendotoxin value $(P<0.05)$. In group II stroke index increased progressively during isoproterenol administration and at $13 \mathrm{hr}$ was $23 \%$ above the base line.

Mean circulation time increased sharply $15 \mathrm{~min}$ postendotoxin, being almost 1.5 times longer than controls in both groups. At $60 \mathrm{~min}$ postendotoxin, it was $88 \%$ longer than the control value of group I and $68 \%$ in the group II animals. In group I after a transient decrease during infusion MCT increased, reaching a value 2.5 times that of the control at $13 \mathrm{hr}$, which was a significant change $(P<0.02)$. In group II MCT was markedly shortened during infusion and was only $55 \%$ of control at $13 \mathrm{hr}$, a difference also significant $(P<$ $0.05)$.

Total peripheral resistance was increased in both groups 15 min postendotoxin, but the differences 


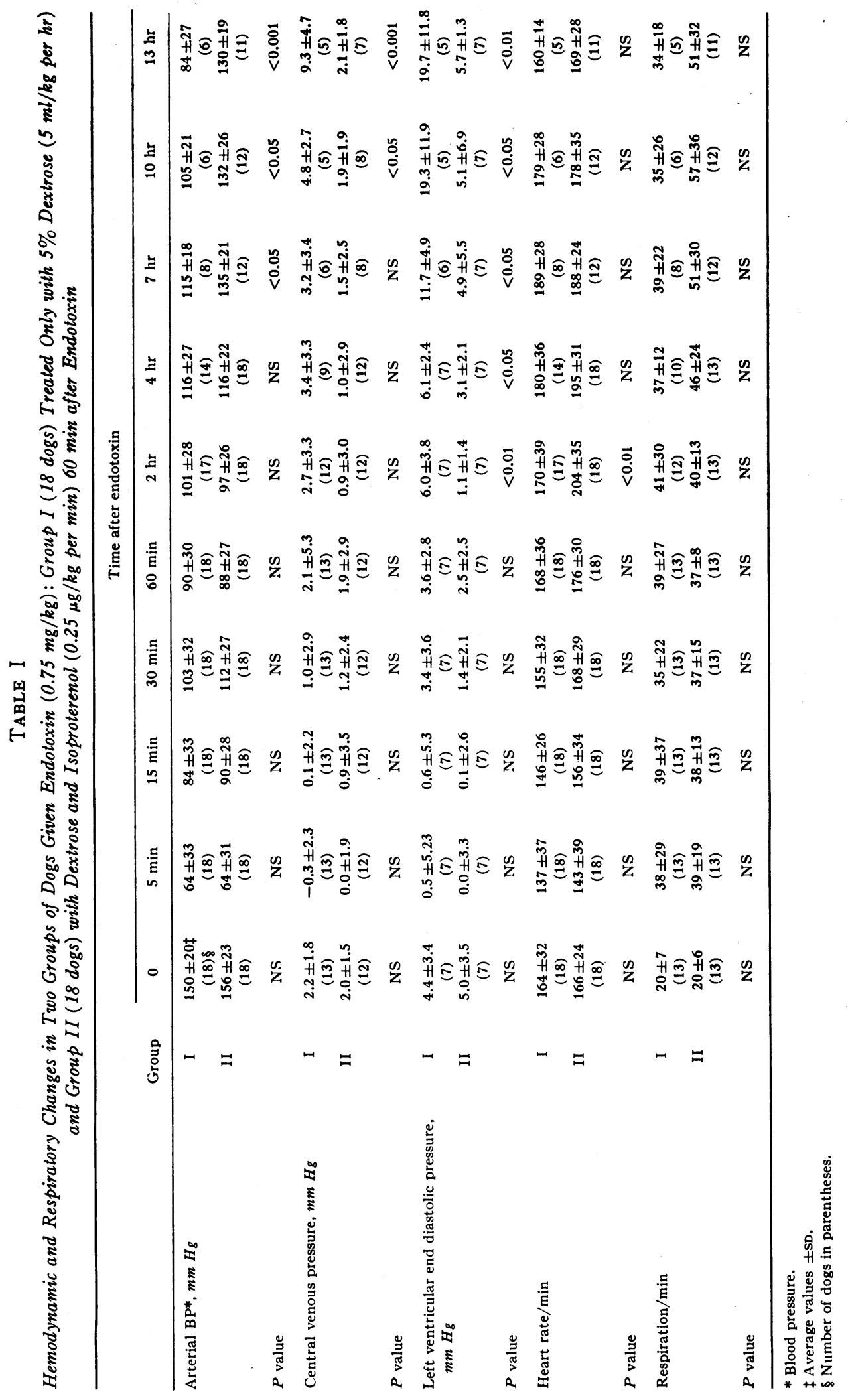




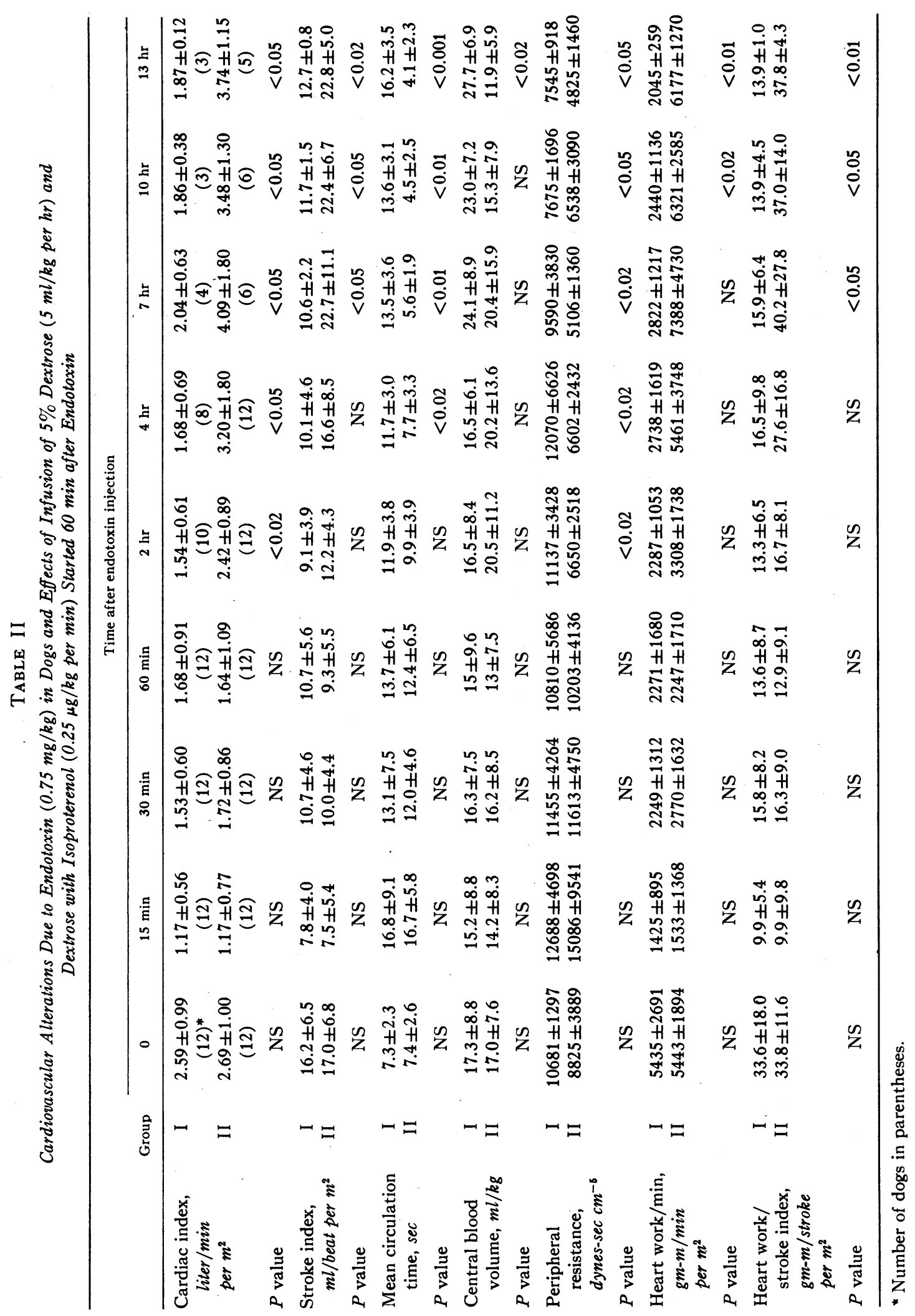


were not statistically significant. TPR almost returned to control levels at $60 \mathrm{~min}$ in group $\mathrm{I}$, but remained at $39 \%$ above the control value in group II. After dextrose infusion in group I, TPR declined gradually to $84 \%$ of the base line level at $13 \mathrm{hr}$. This difference was not significant. In group II after isoproterenol infusion, there was a prompt fall to $86 \%$ of control value at $2 \mathrm{hr}$ postendotoxin and to $56 \%$ at $13 \mathrm{hr}$, which was a significant change $(P<0.05)$.

Central blood volume changes after endotoxin were inconsistent before infusions were started in both groups. The average $\mathrm{CBV}$ in group I decreased to $88 \%$ of the base line, but an analysis of individual results disclosed that out of 12 dogs, 7 showed a decrease and 5 an increase. In group II average CBV decreased to $84 \%$ of the control value and seven animals showed a decrease and five an increase. These changes were not significant. In group I the CBV gradually increased during dextrose infusion and at $13 \mathrm{hr}$ postendotoxin it was $60 \%$ above base line. This was a statistically significant change $(P<0.05)$. CBV in group II initially increased above the control value but at $10 \mathrm{hr}$ postendotoxin it fell and was only $70 \%$ of the base line at $13 \mathrm{hr}$, but this was not significant. The significance of the high CBV during the control period is difficult to interpret. The central shift of blood might have been due to the simultaneous cannulation of both hind legs with the animal in the supine position.

Heart work/min was considerably reduced immediately after endotoxin and the values were still below the base line at $60 \mathrm{~min}$, being $43 \%$ in group I and $41 \%$ in group II. Heart work in group I remained essentially unchanged during $10 \mathrm{hr}$ of infusion, but at $13 \mathrm{hr}$ it was $38 \%$ of the control value, which was a significant difference $(P<0.02)$. In group II, isoproterenol infusion was associated with a progressive increase in heart work, which returned to a level of $13 \%$ above base line at $13 \mathrm{hr}$.

Heart work/stroke index was also reduced after endotoxin. At $60 \mathrm{~min}$ it was $44 \%$ of the control in group I and $38 \%$ in group II. Group I showed no significant change during the infusion period of $10 \mathrm{hr}$, but at $13 \mathrm{hr}$ the value was $41 \%$ of the control, a significant difference with $P<0.02$.

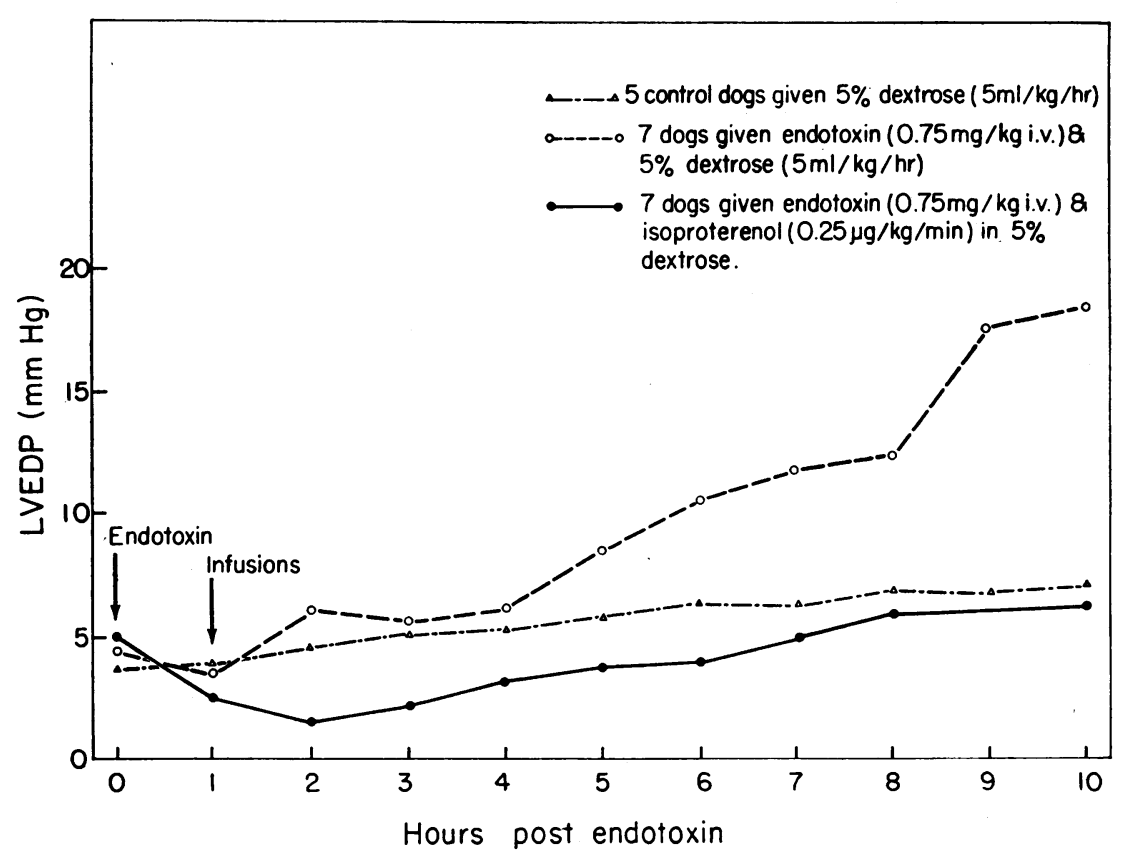

Figure 1 Comparison of changes in left ventricular end diastolic pressure in dogs given only an infusion of $5 \%$ dextrose $(5 \mathrm{ml} / \mathrm{kg}$ per $\mathrm{hr}$ ) with a group of dogs given endotoxin $(0.75 \mathrm{mg} / \mathrm{kg})$ and $60 \mathrm{~min}$ later a similar infusion of dextrose and another group given endotoxin and then treated with dextrose and isoproterenol $(0.25 \mu \mathrm{g} / \mathrm{kg}$ per $\min )$. 
Isoproterenol infusion in group II was associated with a progressive augmentation of heart work reaching a value of $12 \%$ above the base line level.

Influence of type of infusion upon left ventricular end diastolic pressure ( $L V E D P)$. An assessment was made of the effects of comparable blood expansion on LVEDP and of the functional state of the myocardium during a long period of anesthesia. 19 anesthetized dogs included five controls receiving only $5 \%$ dextrose, seven given endotoxin and dextrose, and seven endotoxin and isoproterenol. The results are shown in Fig. 1. The base line LVEDP value in the controls rose progressively during infusion from $3.8 \pm 0.8 \mathrm{~mm} \mathrm{Hg}$ to $7.0 \pm 1.0$ at $10 \mathrm{hr}$, which was still within the normal range, and reflected unimpaired myocardial function. After $5 \mathrm{hr}$ of infusion the rise in LVEDP in dogs given endotoxin and dextrose was significantly greater than in the foregoing controls $(P<0.05)$ and in those given endotoxin and isoproterenol $(P<0.02)$. The isoproterenolinfused values were not statistically different from the controls.

Comparison of left ventricular function curves in dogs given endotoxin and treated with infusions of dextrose or isoproterenol. A reduction in myocardial efficiency was also demonstrated with left ventricular function curves, Fig. 2 (26). The curves were constructed by plotting LVEDP values against the stroke work of the heart, employing consecutive values after initiating infusions. Cardiac rates were not controlled because of the experimental design, but did not differ statistically. Similar distribution curves were obtained by substituting minute work for stroke work. Values were obtained for group I animals (endotoxin plus dextrose), group II animals (endotoxin plus isoproterenol), and for five dogs given only dextrose. The curve for group I was a slightly elevated flat type, reflecting a minor increase in heart work with the initial rise in LVEDP. As LVEDP rose the heart work actually decreased. A distinctly different curve in group II showed a marked increase in heart work with but small increments of LVEDP. The curve of the controls was similar to that of group II. Analysis of these curves shows that myocardial function was markedly improved with isoproterenol in contrast with the ineffectiveness of dextrose.

\section{Mortality}

No animals in either of the treated groups died within the control period of $60 \mathrm{~min}$ postendotoxin.

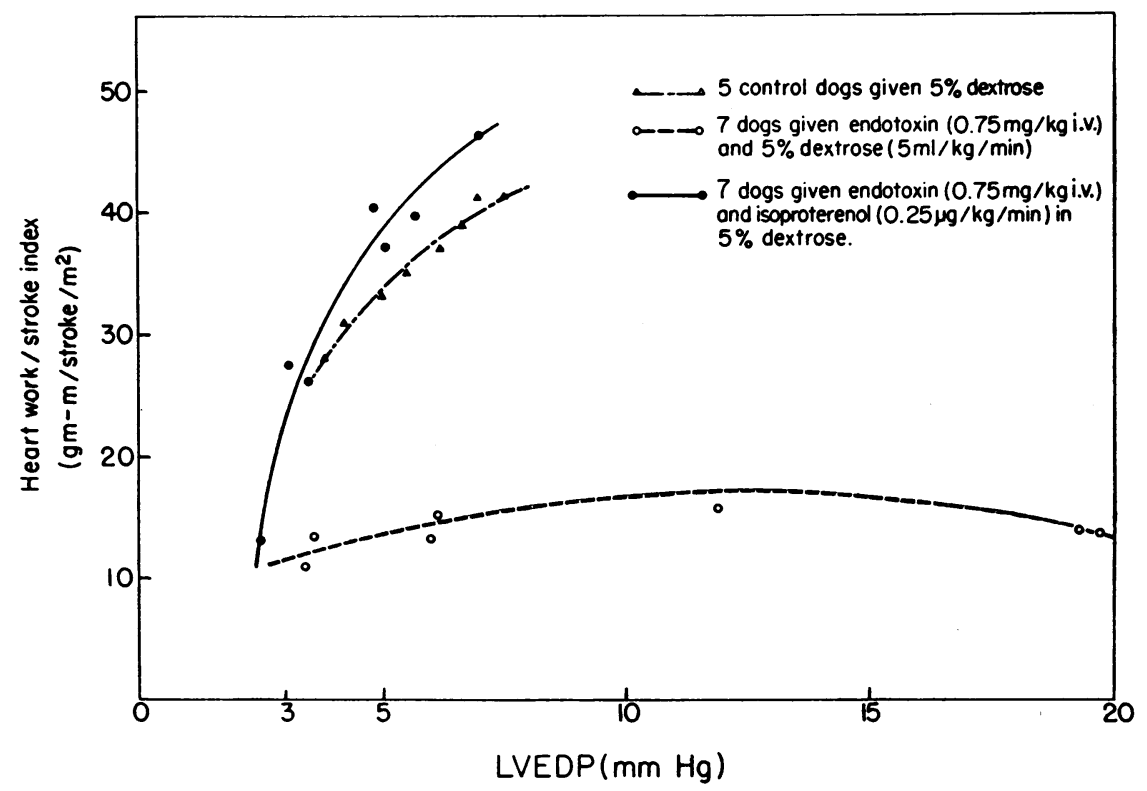

FIGURE 2 Comparison of left ventricular function curves in intact dogs with a group of dogs given i.v. endotoxin $(0.75 \mathrm{mg} / \mathrm{kg})$ and $60 \mathrm{~min}$ later infusion of $5 \%$ dextrose ( $5 \mathrm{ml} / \mathrm{kg}$ per $\mathrm{hr}$ ) and another group given endotoxin and then treated with dextrose and isoproterenol $(0.25 \mu \mathrm{g} / \mathrm{kg}$ per $\mathrm{min})$. 
TABLE III

Effects of Endotoxin $(0.75 \mathrm{mg} / \mathrm{kg})$ i.v. on Blood Lactate, Pyruvate, and $\mathrm{pH}$ in Dogs and Changes

\begin{tabular}{|c|c|c|c|c|c|c|}
\hline & & & & & & Time after \\
\hline & Group & & 0 & $15 \mathrm{~min}$ & $30 \mathrm{~min}$ & $60 \mathrm{~min}$ \\
\hline $\begin{array}{r}\text { Lactic acid, } \\
m E q / \text { liter }\end{array}$ & $\begin{array}{r}\text { I } \\
\text { II }\end{array}$ & $\begin{array}{l}1.56 \\
1.98\end{array}$ & $\begin{array}{l} \pm 1.02 \\
\pm 1.40\end{array}$ & $\begin{array}{l}4.41 \pm 1.65 \\
5.00 \pm 1.57\end{array}$ & $\begin{array}{l}4.14 \pm 1.60 \\
4.28 \pm 2.12\end{array}$ & $\begin{array}{l}4.13 \pm 1.71 \\
4.57 \pm 1.84\end{array}$ \\
\hline $\begin{array}{l}\text { Pyruvic acid, } \\
m E q / \text { liter }\end{array}$ & $\begin{array}{r}\text { I } \\
\text { II }\end{array}$ & $\begin{array}{l}0.08 \\
0.085\end{array}$ & $\begin{array}{l}5 \pm 0.044 \\
5 \pm 0.061\end{array}$ & $\begin{array}{l}0.143 \pm 0.050 \\
0.147 \pm 0.067\end{array}$ & $\begin{array}{l}0.138 \pm 0.049 \\
0.149 \pm 0.070\end{array}$ & $\begin{array}{l}0.155 \pm 0.081 \\
0.153 \pm 0.057\end{array}$ \\
\hline $\begin{array}{c}\text { Lactic acid/ } \\
\text { Pyruvic acid } \\
m E q / \text { liter }\end{array}$ & $\begin{array}{r}\text { I } \\
\text { II }\end{array}$ & $\begin{array}{l}17.7 \\
22.3\end{array}$ & $\begin{array}{l} \pm 6.9 \\
\pm 7.7\end{array}$ & $\begin{array}{ll}33.6 & \pm 16.2 \\
48.2 & \pm 48.2\end{array}$ & $\begin{array}{ll}31.0 & \pm 10.3 \\
39.8 & \pm 44.3\end{array}$ & $\begin{array}{l}29.2 \pm 11.3 \\
30.5 \pm 9.5\end{array}$ \\
\hline $\begin{array}{l}\text { Lactic acid excess, } \\
\quad m E q / \text { liter }\end{array}$ & $\begin{array}{r}\text { I } \\
\text { II }\end{array}$ & & & $\begin{array}{l}2.02 \pm 1.41 \\
1.80 \pm 1.99\end{array}$ & $\begin{array}{l}1.83 \pm 1.15 \\
1.03 \pm 2.51\end{array}$ & $\begin{array}{l}1.21 \pm 1.21 \\
1.22 \pm 1.64\end{array}$ \\
\hline Blood pH & $\begin{array}{r}\text { I } \\
\text { II }\end{array}$ & $\begin{array}{l}7.41 \\
7.44\end{array}$ & $\begin{array}{l} \pm 0.08 \\
\pm 0.07\end{array}$ & $\begin{array}{l}7.29 \pm 0.10 \\
7.32 \pm 0.08\end{array}$ & $\begin{array}{l}7.33 \pm 0.12 \\
7.32 \pm 0.12\end{array}$ & $\begin{array}{l}7.33 \pm 0.13 \\
7.31 \pm 0.14\end{array}$ \\
\hline No. of dogs & $\begin{array}{r}\text { I } \\
\text { II }\end{array}$ & & $\begin{array}{l}18 \\
18\end{array}$ & $\begin{array}{l}18 \\
18\end{array}$ & $\begin{array}{l}18 \\
18\end{array}$ & $\begin{array}{l}18 \\
18\end{array}$ \\
\hline
\end{tabular}

In group I, treated only with $5 \%$ dextrose, 10 out of 18 dogs died during the infusion, whereas in group II treated with isoproterenol, only 2 of 18 died. In a $72 \mathrm{hr}$ period 15 of 18 died in group I and 8 of 18 in group II. In both instances the difference was highly significant $(P<0.001)$.

Effects of endotoxin on blood pyruvate, lactate, and $p H$. The values for pyruvate, lactate, and $\mathrm{pH}$ before and after endotoxin are shown in Table III.

Blood lactic acid increased significantly in both groups at $15 \mathrm{~min}$ postendotoxin, being 3 and 2.5 times above control levels $(P<0.01$ in both groups). At 60 min postendotoxin corresponding concentrations were approximately 2.5 times higher than in controls $(P<0.02$ in both groups) Blood lactic acid in group. I fell transiently during infusion but finally rose to $53 \%$ above the control level at $13 \mathrm{hr}$, which was not a statistically significant difference. In group II, blood lactic acid rose during infusion reaching a maximum $4 \mathrm{hr}$ postendotoxin and gradually declined to $33 \%$ above base line, which was not significant. In addition, the difference between the groups at $13 \mathrm{hr}$ was not statistically significant.

Blood pyruvic acid increased after endotoxin to a maximum of $82 \%$ above control in group I and $80 \%$ in group II at $60 \mathrm{~min}$. The increase was statistically significant $(P<0.01$ in both groups $)$.
During infusion in group I, pyruvic acid declined gradually to $56 \%$ of the control value at $13 \mathrm{hr}$. In group II it rose transiently above the base line and then declined to $78 \%$ of the control level at $13 \mathrm{hr}$. The differences within both groups were not statistically significant. The differences between the groups, likewise, were not significant.

Lactate-pyruvate ratios rose to a maximum at 15 min postendotoxin in both groups $(P<0.05)$. At $60 \mathrm{~min}$ the ratios were $68 \%$ and $37 \%$ above the base line in group I and II, respectively. The ratio in group I rose during infusion to a level 2.5 times the control at $2 \mathrm{hr}$ postendotoxin and remained essentially unchanged until $13 \mathrm{hr}$ when it rose significantly to a level four times the control $(P<0.05)$. The ratio in group II given isoproterenol remained essentially unchanged with a rise at $13 \mathrm{hr}$ to a level twice that of the control, which was not statistically significant. The rise in group I was due mainly to a sharp increase in lactate, whereas in group II the rise was due to a decrease in pyruvate. The difference between the two groups was not statistically significant.

Lactic acid excess was maximal at 15 min postendotoxin and decreased slightly within $60 \mathrm{~min}$ in both groups. In group I, lactic acid excess remained almost unchanged, except for a transient fall between 7 and $10 \mathrm{hr}$ and a sharp rise at $13 \mathrm{hr}$. 
Due to Infusion of $5 \%$ Dextrose $(5 \mathrm{ml} / \mathrm{kg}$ per $\mathrm{hr})$ and Dextrose with Isoproterenol $(0.25 \mu \mathrm{g} / \mathrm{kg}$ per min)

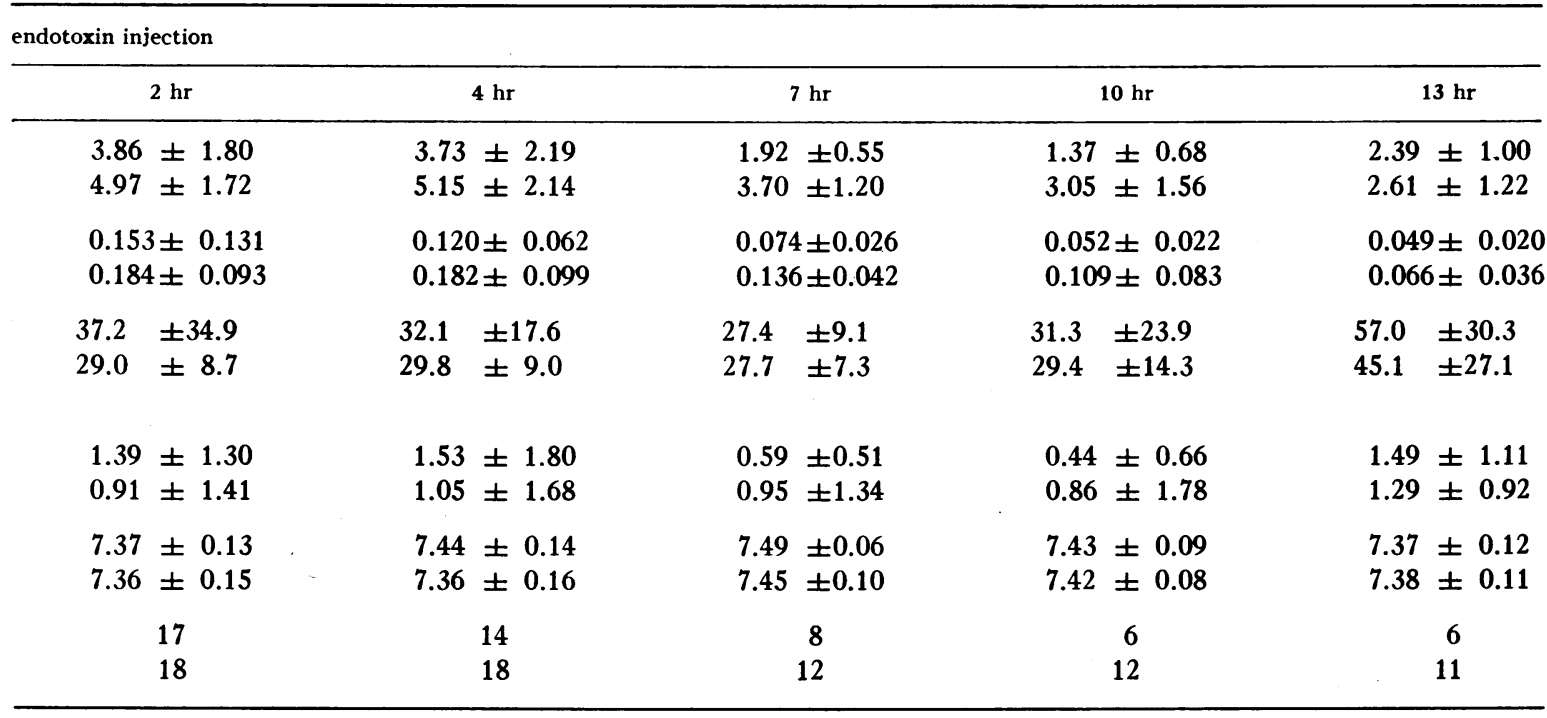

In group II, lactic acid excess decreased slightly after the infusion of isoproterenol and remained essentially unchanged until $13 \mathrm{hr}$ when an increase occurred. The difference between the two groups at 2 and $13 \mathrm{hr}$ was significant $(P<0.001$ and $P<$ $0.05)$. However, differences within the groups were not significant.

Blood $p H$ in both groups declined significantly

TABLE IV

Comparison of Cardiac Index and Blood Lactic Acid Excess with Outcome in Dogs Given Dextrose or Isoproterenol

\begin{tabular}{|c|c|c|c|c|c|c|c|c|c|}
\hline & \multicolumn{9}{|c|}{ Time after endotoxin injection } \\
\hline & $\mathbf{0}$ & $15 \mathrm{~min}$ & $30 \mathrm{~min}$ & $60 \mathrm{~min}$ & $2 \mathrm{nr}$ & $4 \mathrm{hr}$ & $7 \mathrm{hr}$ & $10 \mathrm{hr}$ & $13 \mathrm{hr}$ \\
\hline \multicolumn{10}{|c|}{ Dogs dying within $72 \mathrm{hr}$ and treated with $5 \%$ dextrose } \\
\hline $\begin{array}{l}\text { Lactic acid excess, } \\
\text { mEq/liter }\end{array}$ & & $\begin{array}{c}2.14 \pm 1.58 \\
(15)\end{array}$ & $\begin{array}{c}1.92 \pm 1.02 \\
(15)\end{array}$ & $\begin{array}{c}1.22 \pm 0.98 \\
(15)\end{array}$ & $\begin{array}{c}1.58 \pm 0.90 \\
(13)\end{array}$ & $\begin{array}{c}1.82 \pm 0.92 \\
(11)\end{array}$ & $\begin{array}{c}0.67 \pm 0.42 \\
(6)\end{array}$ & $\begin{array}{c}0.49 \pm 0.26 \\
(5)\end{array}$ & $\begin{array}{c}1.94 \pm 0.81 \\
(4)\end{array}$ \\
\hline $\begin{array}{l}\text { Cardiac index, } \\
\text { liter } / \text { min per } m^{2}\end{array}$ & $\begin{array}{c}2.60 \pm 1.00 \\
(10)^{*}\end{array}$ & $\begin{array}{c}1.19 \pm 0.56 \\
(10)\end{array}$ & $\begin{array}{c}1.50 \pm 0.55 \\
(10)\end{array}$ & $\begin{array}{c}1.66 \pm 1.00 \\
(10)\end{array}$ & $\begin{array}{c}1.60 \pm 0.67 \\
(8)\end{array}$ & $\begin{array}{c}1.76 \pm 0.70 \\
(7)\end{array}$ & $\begin{array}{c}1.90 \pm 0.70 \\
(4)\end{array}$ & $\begin{array}{c}1.88 \pm 0.13 \\
(2)\end{array}$ & $\begin{array}{c}1.86 \pm 0.12 \\
(2)\end{array}$ \\
\hline \multicolumn{10}{|c|}{ Dogs dying within $72 \mathrm{hr}$, treated with $5 \%$ dextrose and isoproterenol $(0.25 \mu \mathrm{g} / \mathrm{kg}$ per min) } \\
\hline $\begin{array}{l}\text { Lactic acid excess, } \\
\quad m E q / \text { liter }\end{array}$ & & $\begin{array}{c}2.80 \pm 1.80 \\
(8)\end{array}$ & $\begin{array}{c}1.29 \pm 0.90 \\
(8)\end{array}$ & $\begin{array}{c}1.43 \pm 1.04 \\
(8)\end{array}$ & $\begin{array}{c}1.10 \pm 0.90 \\
(8)\end{array}$ & $\begin{array}{c}1.47 \pm 1.00 \\
(8)\end{array}$ & $\begin{array}{c}1.23 \pm 0.72 \\
(5)\end{array}$ & $\begin{array}{c}1.14 \pm 0.61 \\
(5)\end{array}$ & $\begin{array}{c}2.30 \pm 0.90 \\
(4)\end{array}$ \\
\hline $\begin{array}{l}\text { Cardiac index, } \\
\quad \text { liter } / \text { min per } m^{2}\end{array}$ & $\begin{array}{c}2.44 \pm 1.00 \\
(6)\end{array}$ & $\begin{array}{c}0.90 \pm 0.50 \\
(6)\end{array}$ & $\begin{array}{c}1.23 \pm 0.42 \\
(6)\end{array}$ & $\begin{array}{c}1.17 \pm 0.64 \\
(6)\end{array}$ & $\begin{array}{c}2.02 \pm 0.62 \\
(6)\end{array}$ & $\begin{array}{c}2.13 \pm 1.02 \\
(6)\end{array}$ & $\begin{array}{c}1.79 \pm 1.53 \\
(6)\end{array}$ & $\begin{array}{c}1.72 \pm 0.68 \\
(2)\end{array}$ & $\begin{array}{c}1.14 \\
(1)\end{array}$ \\
\hline \multicolumn{10}{|c|}{ Dogs surviving $72 \mathrm{hr}$ and treated with $5 \%$ dextrose } \\
\hline $\begin{array}{l}\text { Lactic acid excess, } \\
\quad m E q / \text { liter }\end{array}$ & & $\begin{array}{c}1.88 \pm 1.63 \\
(3)\end{array}$ & $\begin{array}{c}1.32 \pm 1.24 \\
(3)\end{array}$ & $\begin{array}{c}1.13 \pm 1.00 \\
(3)\end{array}$ & $\begin{array}{c}0.60 \pm 0.30 \\
(3)\end{array}$ & $\begin{array}{c}0.46 \pm 0.25 \\
(3)\end{array}$ & $\begin{array}{c}0.33 \pm 0.09 \\
\text { (2) }\end{array}$ & $\begin{array}{c}0.32 \pm 0.08 \\
(2)\end{array}$ & $\begin{array}{c}0.59 \pm 0.20 \\
(2)\end{array}$ \\
\hline $\begin{array}{l}\text { Cardiac index, } \\
\quad \text { liter } / \text { min per } m^{2}\end{array}$ & $\begin{array}{c}2.57 \pm 0.51 \\
(2)\end{array}$ & $\begin{array}{c}1.09 \pm 0.43 \\
(2)\end{array}$ & $\begin{array}{c}1.68 \pm 0.64 \\
(2)\end{array}$ & $\begin{array}{c}1.77 \pm 0.23 \\
(2)\end{array}$ & $\begin{array}{c}1.28 \pm 0.40 \\
(2)\end{array}$ & $\begin{array}{l}1.41 \\
(1)\end{array}$ & $\begin{array}{c}1.69 \\
(1)\end{array}$ & $\begin{array}{c}2.44 \\
(1)\end{array}$ & $\begin{array}{l}2.90 \\
(1)\end{array}$ \\
\hline \multicolumn{10}{|c|}{ Dogs surviving $72 \mathrm{hr}$, treated with $5 \%$ dextrose and isoproterenol $(0.25 \mu \mathrm{g} / \mathrm{kg}$ per min) } \\
\hline $\begin{array}{l}\text { Lactic acid excess, } \\
\quad m E q / \text { liter }\end{array}$ & & $\begin{array}{c}1.00 \pm 0.51 \\
(10)\end{array}$ & $\begin{array}{c}0.92 \pm 0.58 \\
(10)\end{array}$ & $\begin{array}{c}1.06 \pm 0.53 \\
(10)\end{array}$ & $\begin{array}{c}0.77 \pm 0.50 \\
(10)\end{array}$ & $\begin{array}{c}0.73 \pm 0.54 \\
(10)\end{array}$ & $\begin{array}{c}0.75 \pm 0.41 \\
(7)\end{array}$ & $\begin{array}{c}0.66 \pm 0.31 \\
(7)\end{array}$ & $\begin{array}{c}0.71 \pm 0.44 \\
(7)\end{array}$ \\
\hline $\begin{array}{l}\text { Cardiac index, } \\
\quad \text { liter } / \mathrm{min} \text { per } \mathrm{m}^{2}\end{array}$ & $\begin{array}{c}2.60 \pm 1.07 \\
(6)\end{array}$ & $\begin{array}{c}1.10 \pm 0.55 \\
\text {. } \quad(6)\end{array}$ & $\begin{array}{c}1.21 \pm 0.93 \\
(6)\end{array}$ & $\begin{array}{c}1.60 \pm 0.81 \\
(6)\end{array}$ & $\begin{array}{c}2.82 \pm 0.98 \\
(6)\end{array}$ & $\begin{array}{c}4.09 \pm 1.99 \\
(6)\end{array}$ & $\begin{array}{c}4.39 \pm 0.70 \\
(4)\end{array}$ & $\begin{array}{c}4.29 \pm 0.48 \\
(4)\end{array}$ & $\begin{array}{c}4.14 \pm 0.84 \\
(4)\end{array}$ \\
\hline
\end{tabular}



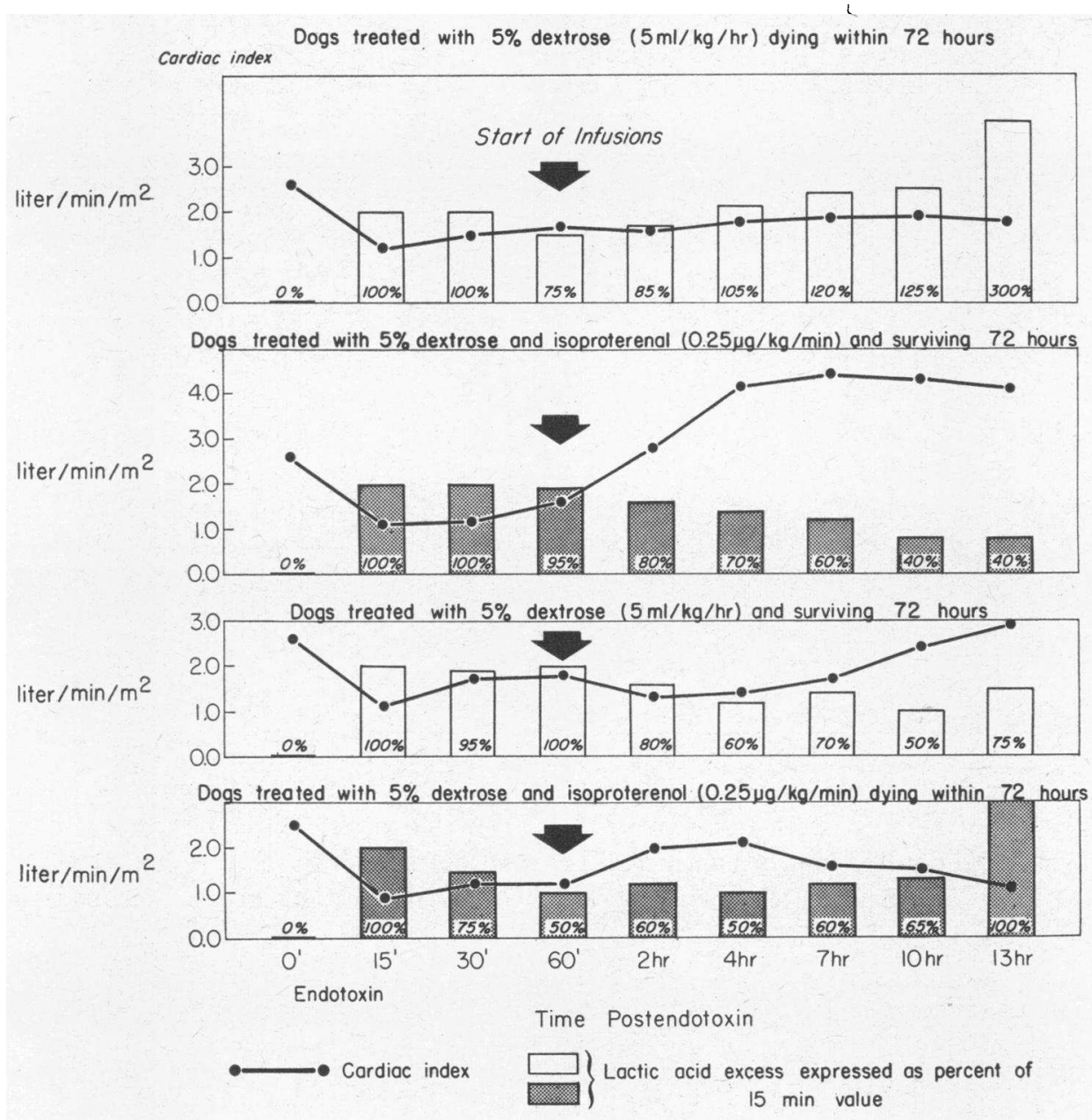

Figure 3 Comparison of cardiac index and blood lactic acid excess in dogs given endotoxin and treated with $5 \%$ dextrose $(5 \mathrm{ml} / \mathrm{kg}$ per hr$)$ or with dextrose and isoproterenol $(0.25 \mu \mathrm{g} / \mathrm{kg}$ per min). Comparisons were made in the two groups of dogs dying within $72 \mathrm{hr}$ after endotoxin and those surviving beyond $72 \mathrm{hr}$.

at $15 \mathrm{~min}$ postendotoxin $(P<0.001)$, and remained below the control level, except for a transient rise above that value at $7 \mathrm{hr}$. At $13 \mathrm{hr}$ in both groups $\mathrm{pH}$ was significantly below the base line $(P<0.02)$.

Relationship of survival to cardiac index and lactic acid excess. An analysis of cardiac indices and lactic acid relative to treatment and outcome is presented in Table IV. Data on the same group of dogs have already been presented with reference only to the type of infusion (Tables II and III). All dogs dying within $72 \mathrm{hr}$ had low cardiac indices, while survivors had significantly higher indices beginning $2 \mathrm{hr}$ postendotoxin. At $4 \mathrm{hr}$ survivors receiving isoproterenol had higher indices than nonsurvivors (Fig. 3). Lactic acid excess was statistically greater in nonsurvivors, regardless of treatment, at 2,4 , and $13 \mathrm{hr}$ postendotoxin. However, at $15 \min 31 \%$ (4 of 13 ) of survivors and $32 \%$ ( 7 of 22 ) of nonsurvivors had blood lactic acid excess of less than $1 \mathrm{mEq} /$ liter. This would suggest that an analysis of data shortly after initiating infusions is of prognostic significance. Survivors demonstrated a progressive decline in lactic acid excess, whereas the values remained elevated in nonsurvivors throughout the experimental period (Table IV). It should be noted that an apparent fall in average lactic acid excess in nonsurvivors (Table IV) is due to the loss of dogs with high levels. Actually, there was a continuous rise in individual animals still surviving (Fig. 3). 


\section{DISCUSSION}

The progressive and rapidly changing hemodynamic and metabolic patterns in experimental canine endotoxin shock reflect the complexity of this clinical entity $(12,18,27-35)$. In the canine there is a temporary improvement and recovery of the arterial blood pressure after the initial hypotension immediately following endotoxin. In the majority of animals this temporary improvement is followed by progressive hypotension and acidosis, and death occurs. Knowledge of the basic mechanisms involved in the onset of irreversible shock and a progressive fatal outcome is particularly incomplete. Ultimate collapse is vaguely attributed to a deficient supply of blood to vital organs, either as a result of excessive vasoconstriction $(36,37)$ or to precapillary shunting caused by widespread precapillary arteriovenous dilatation (38). Increased blood viscosity and the stagnation of blood are other factors considered responsible for the terminal cardiovascular collapse (39). Little information is available on the role of the myocardium in endotoxin shock and the effect of treatment on cardiac function.

In the present investigation the hemodynamic changes followed the previously reported pattern. The blood lactate-pyruvate ratio increased, lactic acid excess appeared, and a fall in $\mathrm{pH}$ occurred $(35,40-41)$. Huckabee $(42,43)$ has expressed lactate-pyruvate ratios as "excess lactate," indicating tissue hypoxia, but this conclusion is not generally accepted (44-46). Since oxygen debt was not measured in the present studies it is not possible to evaluate the concept of lactate excess. The significance of low lactic acid excess levels before treatment is difficult to interpret. An equal proportion of survivors and nonsurvivors had low values. The immediate rise in postendotoxin lactic acid excess is stated to be inversely proportional to the dose of endotoxin (47). Very low values of excess lactate have been reported in moribund patients (48). From our data persistent elevations of lactic acid excess indicate a poor prognosis, whereas progressively declining values suggested a favorable outcome.

The hemodynamic observations in the present studies have been extended to the later stages of endotoxin shock because few data have been documented for this period. Measurements of myocardial function were carried out for $13 \mathrm{hr}$ post- endotoxin and demonstrated a progressive rise in LVEDP that could not be attributed to an expansion of blood volume following infusion (Fig. 1). This finding together with associated low cardiac index, rising CVP, increased CBV, tachycardia, and declining arterial pressure indicated progressive myocardial insufficiency. Further evidence of myocardial failure was obtained from the analysis of left ventricular function curves (Fig. $2)$. Dogs given endotoxin had low flat curves. Diminished work/stroke and a marked increase in LVEDP without an increase in heart work are characteristically found in failing hearts (49).

It was interesting to note that although death was associated with respiratory failure, the arrest was always preceded by a sharp decline in cardiac index with the arterial pressure usually remaining unchanged. These observations suggest that the mechanism of death is primarily of cardiovascular origin and the cessation of respiration is a secondary phenomenon.

Infusion of dextrose alone after endotoxin resulted in only a slight or temporary improvement of the parameters studied. Myocardial efficiency was not increased and the mortality rate was high. On the other hand, the addition of isoproterenol resulted in a marked improvement of cardiovascular function, enduring through the $12 \mathrm{hr}$ of treatment. With the dose of isoproterenol used, the rise in cardiac index was due more to an increase in stroke volume than rate. Tachycardia began to subside after $3 \mathrm{hr}$ of infusion and the rate was in the control range at $12 \mathrm{hr}$ of treatment. Left ventricular function curves demonstrated a dramatic improvement in myocardial function and the mortality rate was significantly reduced.

These data support the concept that myocardial failure occurs in experimental canine endotoxin shock (14). Although barbiturate anesthesia may be associated with some of the hemodynamic and metabolic alterations described, this factor was controlled in the present investigations. Dogs not given endotoxin, but otherwise treated in comparable manner, did not show any significant deterioration of myocardial function as reflected in normal LVEDP up to $10 \mathrm{hr}$ (Fig. 1). In addition the blood pressure remained satisfactory throughout the same period of time. Available knowledge indicates that endotoxin does not have a significant direct effect on the myocardium. Therefore, it 
would appear that myocardial failure was secondary to prolonged shock. It is possible that isoproterenol is beneficial along a "common pathway" of late shock regardless of the initial cause of shock.

It is difficult to assess the precise role of isoproterenol in the improvement of myocardial failure in canine endotoxin shock. There appears to be a relationship between the ionotropic effect of the drug and survival. It is possible that the increase in cardiac index and arteriolar dilatation results in improved tissue perfusion. In addition, venous constriction leads to a reduction in the distended venous bed and an increased return of the blood to the heart (50). However, isoproterenol may also have beneficial respiratory and metabolic effects (51).

\section{ACKNOWLEDGMENTS}

The technical assistance of Arlene Gran is appreciated.

Dr. Boleslaw Starzecki was a postdoctoral fellow of the U. S. Public Health Services, training grant 5 T1 AI 194-05. This investigation was supported by U. S. Public Health Services research grant AI 04415-06.

\section{REFERENCES}

1. Spink, W. W. 1962. Endotoxin shock. Ann. Internal Med. 57: 538.

2. Gilbert, R. P. 1960. Mechanisms of the hemodynamic effects of endotoxin. Physiol. Rev. 40: 245.

3. Raskova, H., and J. Vanecek. 1964. Pharmacology of bacterial toxins. Pharmacol. Rev. 16: 1 .

4. Halmagyi, D. F. J., B. Starzecki, and G. J. Horner. 1963. Mechanism and pharmacology of endotoxin shock in sheep. J. Appl. Physiol. 18: 544.

5. Duff, J. H., G. Malave, D. I. Peretz, H. M. Scott, and L. D. MacLean. 1965. The hemodynamics of septic shock in man and in the dog. Surgery. 58: 174.

6. Vick, J. A., H. P. Ciuchta, and J. H. Manthei. 1965. Use of isoproterenol and phenoxybenzamine in treatment of endotoxin shock. J. Pharmacol. Exptl. Therap. 150: 382.

7. Starzecki, B., J. L. Reddin, and W. W. Spink. 1968. Effect of isoproterenol on survival in canine endotoxin shock. Ann. Surg. 167: 35.

8. Krasnow, N., E. L. Rolett, P. M. Yurchak, W. B. Hood, Jr., and R. Gorlin. 1964. Isoproterenol and cardiovascular. performance. Am. J. Med. 37: 514

9. Goodman, L. S., and A. Gilman. 1965. The Pharmacological Basis of Therapeutics, The Macmillan Company, New York. 3rd edition. 497.

10. Sandler, H., H. T. Dodge, and H. V. Murdaugh. 1961. Effect of isoproterenol on cardiac output and renal function in congestive heart failure. Am. Heart J. 62: 643
11. Elliott, W. C., and R. Gorlin. 1966. Isoproterenol in treatment of heart disease. Hemodynamic effects in circulatory failure. J. Am. Med. Assoc. 197: 315.

12. Weil, M. H., L. D. MacLean, M. B. Visscher, and W. W. Spink. 1956. Studies on the circulatory changes in the dog produced by endotoxin from gram-negative microorganisms. J. Clin. Invest. 35: 1191.

13. Hinshaw, L. B., R. P. Gilbert, H. Kuida, and M. B. Visscher. 1958. Peripheral resistance changes and blood pooling after endotoxin in eviscerated dogs. Am. J. Physiol. 195: 631.

14. Alican, F., M. L. Dalton, Jr., and J. D. Hardy. 1962. Experimental endotoxin shock. Circulatory changes with emphasis upon cardiac function. Am. J. Surgery. 103: 702 .

15. Siegel, J. H., and M. Fabian. 1967. Therapeutic advantages of an inotropic vasodilator in endotoxin shock. J. Am. Med. Assoc. 200: 696.

16. Halberg, F., and W. W. Spink. 1956. The influence of Brucella somatic antigen (endotoxin) upon the temperature rhythm of intact mice. Lab. Invest. 5: 283.

17. Guyton, A. C., J. H. Satterfield, and J. W. Harris. 1952. Dynamics of central venous resistance with observations on static blood pressure. Am. J. Physiol. 169: 691 .

18. Nicholson, J. W., and E. H. Wood. 1951. Estimation of cardiac output and Evans Blue space in man, using an oximeter. J. Lab. Clin. Med. 38: 588.

19. Lilienfield, L. S., and R. D. Kovach. 1956. Simplified method for calculating flow, mean circulating time and downslope from indicator-dilution curves. Proc. Soc. Exptl. Biol: Med. $91: 595$.

20. Spector, W. S., editor. 1956. In Handbook of Biological Data. W. B. Saunders Co., Philadelphia. 175.

21. Barker, S. B., and W. H. Summerson. 1941. The colorimetric determination of lactic acid in biological material. J. Biol. Chem. 138: 535.

22. Goldberg, E. B., H. M. Nitowsky, and S. P. Colowick. 1965. The role of glycolysis in the growth of tumor cells. J. Biol. Chem. 240: 2791.

23. Huckabee, W. E. 1958. Relationships of pyruvate and lactate during anaerobic metabolism. I. Effects of infusion of pyruvate or glucose and of hyperventilation. J. Clin. Invest. 37: 244.

24. Bancroft, H. 1957. Introduction to Biostatistics. P. B. Hoeber, Inc., New York.

25. Entwisle, G., and Reinke, W. A. 1965. Statistical evaluation of medical information. Bulletin Univ. Maryland School Med. 50: 32.

26. Sarnoff, S. J. 1955. Myocardial contractility as described by ventricular function curves; observations on Starling's law of the heart. Physiol. Rev. 35: 107.

27. Hinshaw, L. B., W. W. Spink, J. A. Vick, E. Mallet, and J. Finstad. 1961. Effect of endotoxin on kidney function and renal hemodynamics in the dog. Am. J. Physiol. 201: 144.

28. Zweifach, B. W. 1964. Vascular effects of bacterial endotoxin. In Bacterial Endotoxins. M. Landy and 
W. Braun, editors. Institute of Microbiology, Rutgers, The State University, New Brunswick. 110.

29. Spink, W. W., R. B. Davis, R. Potter, and S. Chartrand. 1964. The initial stage of canine endotoxin shock as an expression of anaphylactic shock: studies on complement titers and plasma histamine concentrations. J. Clin. Invest. 43: 696.

30. Spink, W. W., J. Reddin, S. J. Zak, M. Peterson, B. Starzecki, and E. Seljeskog. 1966. Correlation of plasma catecholamine levels with hemodynamic changes in canine endotoxin shock. J. Clin. Invest. 45: 78.

31. Davis, R. B., W. R. Meeker, and D. G. McQuarrie. 1960. Immediate effects of intravenous endotoxin on serotonin concentrations and blood platelets. Circulation Res. 8: 234.

32. Kobold, E. E., R. Lovell, W. Katz, and A. P. Thal. 1964. Chemical mediators released by endotoxin. Surg. Gynecol. Obstet. 118: 807.

33. Melby, J. C., R. H. Egdahl, I. C. Bossenmaier, and W. W. Spink. 1959. Suppression by cortisol of increased serum-transaminase induced by endotoxin. Lancet. $1: 441$.

34. Weissman, G., and L. Thomas. 1964. On mechanism of tissue damage by bacterial endotoxin. In Bacterial Endotoxins. M. Landy and W. Braun, editors. Institute of Microbiology, Rutgers, The State University, New Brunswick. 602.

35. Sleeman, H. K., P. B. Jennings, and R. M. Hardaway. 1967. Evaluation of biochemical changes associated with experimental endotoxemia. I. Transaminase activity. Surgery. 61: 945.

36. Hinshaw, L. B., J. A. Vick, M. M. Jordan, and L. E. Wittmers. 1962. Vascular changes associated with development of irreversible endotoxin shock. Am. J. Physiol. 202: 103.

37. Lillehei, R. C., J. K. Longerbeam, J. H. Bloch, and W. G. Manax. 1964. The nature of irreversible shock; experimental and clinical observations. Ann. Surg. 160: 682 .

38. Siegel, J. H., M. Greenspan, and L. R. M. Del Guercio. 1967. Abnormal vascular tone, defective oxygen transport and myocardial failure in human septic shock. Ann. Surg. 165: 504.

39. Chien, S., C. Chang, R. J. Dellenback, S. Usami, and M. I. Gregersen. 1966. Hemodynamic changes in endotoxins on carbohydrate metabolism of rabbits.

40. Kun, E., and C. P. Miller. 1948. Effect of bacterial endotoxins on carbohydratae metabolism of rabbits. Proc. Soc. Exptl. Biol. Med. 67: 221.

41. Rosenberg, J. C., and B. F. Rush. 1966. Lethal endotoxin shock. Oxygen deficit, lactic acid levels and other metabolic changes. J. Am. Med. Assoc. 196: 767.

42. Huckabee, W. E. 1958. Relationship of pyruvate and lactate during anaerobic metabolism. II. Exercise and formation of $\mathrm{O}_{2}$-debt. J. Clin. Invest. 37: 255.

43. Huckabee, W. E. 1958. Relationship of pyruvate and lactate during anaerobic metabolism. III. Effect of breathing low-oxygen gases. J. Clin. Invest. 37: 264.

44. Harris, P., M. Bateman, and J. Gloster. 1962. Relations between the cardio-respiratory effects of exercise and the arterial concentration of lactate and pyruvate in patients with rheumatic heart disease. Clin. Sci. 23: 531 .

45. Olson, R. E. 1963. "Excess lactate" and anaerobiosis (editorial). Ann. Intern. Med. 59: 960.

46. Knuttgen, H. G. 1962. Oxygen debt, lactate, pyruvate, and excess lactate after muscular work. J. Appl. Physiol. 17: 639.

47. Rosenberg, J. C., and B. F. Rush. 1965. Basic biochemical difference in endotoxin and hemorrhagic shock. Surg. Forum. 16: 23.

48. Huckabee, W. E. 1961. Abnormal resting blood lactate. II. Lactic acidosis. Am. J. Med. 30: 840.

49. Shaffer, A. B., and L. N. Katz. 1967. Hemodynamic alterations in congestive heart failure. New Engl. J. Med. 276: 853.

50. Kaiser, G. A., J. Ross, Jr., and E. Braunwald. 1964. Alpha and beta adrenergic receptor mechanisms in the systemic venous bed. J. Pharmacol. Exptl. Therap. $144: 156$.

51. Ellis, S. The metabolic effects of epinephrine and related amines. Pharmacol. Rev. 8: 485. 